\title{
Analysis of regional differentiation in waste generation and conclusions for Russia
}

\author{
Oksana Komarova* \\ Ural State University of Economics, 620144, 8 Marta Str., 62, Ekaterinburg, Russia
}

\begin{abstract}
The problem of waste generation and utilization is one of the most important goals of sustainable development in the modern world. The article provides a statistical analysis of the level of waste generation and utilization in Russia, which is assessed as high in comparison with the European Union countries. Based on statistical analysis, a high level of regional differentiation in waste generation and utilization in Russia was determined. On the basis of theoretical and empirical analysis it was revealed that regional differentiation is based on different provision of aregions with natural resources and degree of industrial production development. The key directions for reducing regional differentiation are environmental industrial policy, formation of regional environmental institutions and environmentally-oriented behavior of all economic subjects of the regional economy.
\end{abstract}

\section{Introduction}

In recent decades, the number of sustainable development goals has expanded significantly, including problems in the social sphere, poverty alleviation, etc. Initially, sustainable development was associated with ensuring environmentally friendly growth and active attention to the environment. This goal remains one of the most important in ensuring sustainable development so far [1]. Attention to the environment also includes problems with waste disposal. Studies of waste dynamics and structure, waste management models are relevant in different countries and have their own specifics [2].

Waste is understood as the result of human activity unsuitable for subsequent use: it is "a substance or object that the owner disposes, intends or must dispose" [3; 4, p.15]. The problem of waste management is caused by human activities not only in production but also in consumption [5]. However, the legal and economic interpretations of waste differ, "which leads to inaccuracies in the establishment of norms of accumulation and, as a consequence, errors in determining the scope and plurality of operational management decisions of state and municipal authorities". [6, p.115].

The research notes the main reasons for the formation of problems to increase the amount of waste. First, the main reason underlying the problem of waste is the content of economic activities based on the extraction of resources and their transformation into goods, the possibilities of industrial ecology, the development of the subsequent life cycle

\footnotetext{
* Corresponding author: okkomarova@yandex.ru
} 
of the product and the reluctance of producers to introduce environmentally friendly technologies [3].

Secondly, waste management is largely determined by "ownership rights and emerging transactional costs in separate waste collection and subsequent disposal"; [7, p.466]; the system of formal informal institutions of interaction [8], one of the most important theoretical bases of which is the Coase theorem and mechanisms of market regulation of property rights. F.Biermann notes the high role of institutional factors, such as: the degree of formalization of sustainable development commitments and rules, development of national priorities and regulatory mechanisms consistent with sustainable development goals, integration of sectoral policies and support for flexibility in governance mechanisms [9].

Thirdly, the most important problem directly related to waste generation is the formation of an environmentally-oriented model of human behavior [3; 10]: individual environmental behavior and civic responsibility, as well as waste management ethics. New aspects of ecology-oriented behavior acquire special importance in waste utilization associated with the use of electronic gadgets [11].

Thus, management in the sphere of waste generation and utilization should be based on system-institutional approach based on formation of formal institutions, use of programtarget instruments of state regulation of development [6, p.123; 7].

Management problems in the sphere of waste generation and utilization are actively studied in Russia. As a rule, the research focuses on the problems of a particular region [12; 13], while the problems of a wider range - regional differentiation and peculiarities of regional industrial policy are discussed very rarely. The importance of this problem has determined the purpose of the study - to analyze regional differentiation of Russian regions in the sphere of waste generation and utilization.

\section{Materials and Methods}

The following methods were used to achieve the goal. For the analysis of theoretical and methodological aspects of the problem of waste formation and its use we used the review of scientific research in domestic and foreign literature.

The empirical analysis is based on the use of statistical data of the Russian Federation for 2016-2019 and is based on the method of comparison and quantitative analysis. In order to provide a comprehensive view of the results of the comparative analysis, we used graphical and tabular methods.

Waste statistics in the Russian Federation includes data by regions of the Russian Federation in the context of three groups of indicators: solid waste generation in production and consumption, utilization and decontamination of waste. We used them to characterize and analyze the level of waste generation and utilization. However, the statistics presented in the official statistics differ significantly from country to country, which does not provide comparable cross-country analysis, but provides an opportunity to analyze the level of domestic national problems in waste generation and disposal.

\section{Results and Discussion}

Analysis of waste generation, utilization and decontamination dynamics in Russia (fig. 1) showed that during the period of 2005-2019 the amount of generated waste has increased more than 2.5 times. At the same time, waste utilization and neutralization volumes have grown 3 times and waste disposal has increased 1.83 times. At the same time, the share of waste disposal in 2016-2019 as compared to 2005 increased from $39.7 \%$ to $50-52 \%$, and 
the share of disposed waste decreased: during the same period from $62 \%$ to $33 \%$. Such dynamics testify to the implementation of the concept of sustainable development associated with a clean environment.

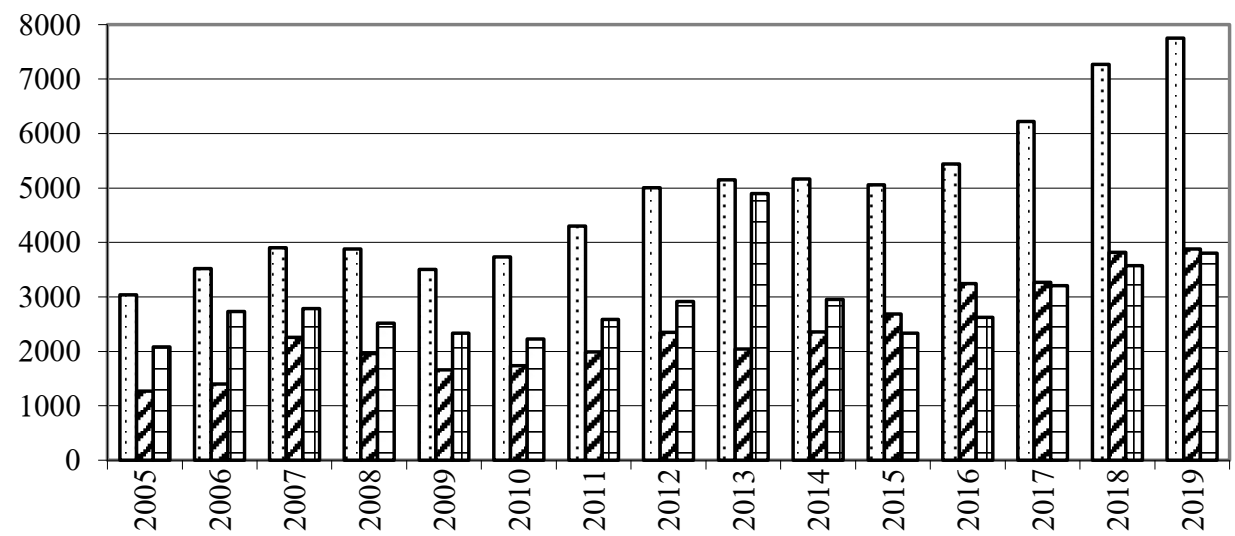

$\square$ production and consumption waste generation - in total;

चutilization and neutralization of production and consumption wastes

$\square$ disposal of production and consumption waste at facilities owned by the enterprise - in total

Fig.1. Formation, utilization, neutralization and disposal of production and consumption waste in the Russian Federation, million tons

In terms of economic activities, the largest amount of production and consumption waste in 2016-2019 was generated by mining, with the share of this type of waste increased from $86.8 \%$ in 2016 to $93.6 \%$ in 2019 . These trends are due to the raw material orientation of the Russian economy. Processing industries generated $10.1 \%$ of waste in 2016, this figure fell to $3.8 \%$ by 2019 , which is comparable to data from the European Union. In general, the structure of waste formation corresponds to the world structure: the largest contribution to waste formation is made by the mining industry.

The analysis of waste management efficiency is most important for the analysis of its utilization and neutralization. Waste recycling dynamics in the mining industry decreased from $61.1 \%$ in 2016 to $49.1 \%$ in 2019 , and by type of economic activity "processing industries" the opposite situation is observed: from 2016 the share of recyclable waste increased from $44.3 \%$ to $59.8 \%$ in 2019 .

The analysis of waste generation and utilization indicators per capita (Table 1) showed that in 2016 there were 36.1 tons of waste per year per capita, the growth of this indicator by 2019 was $42.4 \%$ ( 52.8 tons per capita), which is 7 times higher than the average in the European Union. At the same time, the share of waste recycling per capita in Russia decreased from 59.6\% in 2016 to 50.1\% in 2019. The same indicator in the EU in 2016 was $46.6 \%$ for waste disposal and $36.7 \%$ for recycling.

The analysis of waste generation and utilization per capita without taking into account extractive industries shows relatively European countries a high level of waste generation in Russia (in the EU this indicator was 1.8 tons of waste per capita in 2016, which is 2.7 times lower than the Russian level for the same period). However, on the whole, this indicator is decreasing, which indicates a positive trend in waste management policy and sustainable development. 
Table 1. Formation, utilization and neutralization of waste per capita in Russia, 2016-2019

\begin{tabular}{|c|c|c|c|c|c|}
\hline \multirow{2}{*}{ Index } & \multicolumn{4}{|c|}{ Year } & \multirow{2}{*}{$\begin{array}{l}\text { Rate of increase, } \\
2019 \text { to } 2016, \%\end{array}$} \\
\hline & 2016 & 2017 & 2018 & 2019 & \\
\hline $\begin{array}{l}\text { Production and consumption waste } \\
\text { generation, tons per capita }\end{array}$ & 37,10 & 42,36 & 49,49 & 52,81 & $42,4 \%$ \\
\hline $\begin{array}{l}\text { Utilization and neutralization of } \\
\text { production and consumption waste, tons } \\
\text { per capita }\end{array}$ & 22,11 & 22,23 & 26,01 & 26,45 & $19,6 \%$ \\
\hline Share of recycling in waste generation, $\%$ & 59,6 & 52,5 & 52,6 & 50,1 & - \\
\hline $\begin{array}{c}\text { Production and consumption waste } \\
\text { generation (excluding extracting } \\
\text { industries), tons per capita }\end{array}$ & 4,9 & 3,0 & 2,8 & 3,4 & $-31,2 \%$ \\
\hline $\begin{array}{c}\text { Utilization and neutralization of } \\
\text { production and consumption wastes } \\
\text { (excluding extractive industries), tons per } \\
\text { capita }\end{array}$ & 2,4 & 1,7 & 1,6 & 2,2 & $-10,7 \%$ \\
\hline $\begin{array}{l}\text { Share of recycling in waste generation } \\
\text { (excluding extractive industries), \% }\end{array}$ & 49,9 & 55,9 & 56,1 & 64,9 & - \\
\hline
\end{tabular}

The analysis of regional structure of waste formation, utilization and neutralization on the territory of the Russian Federation (Table 2) has allowed to distinguish a high level of differentiation of regions by these indicators. Thus, in terms of waste generation volumes the difference was 1030 times between regions with high level of waste generation and regions with low level of waste generation, in terms of utilization the difference between these groups was 1616 times and in terms of production and consumption waste disposal at enterprises - 615 times.

The group of regions with high level of waste generation includes regions with high share in regional gross output of extractive industries and industry. The group of regions with low waste generation includes regions with a low share of mining industry, predominance of agriculture and a highly developed recreational complex.

Table 2. Waste generation, utilization and neutralization in regions of Russian Federation, 2016

\begin{tabular}{|c|c|c|c|c|c|c|}
\hline $\begin{array}{c}\text { Regions with high } \\
\text { waste generation }\end{array}$ & $\begin{array}{c}\text { PC } \\
\text { WG }\end{array}$ & $\begin{array}{c}\text { SPC } \\
\mathbf{W G}, \\
\mathbf{\%}\end{array}$ & $\begin{array}{c}\text { UDPC } \\
\mathbf{W G},\end{array}$ & $\begin{array}{c}\text { Regions with low } \\
\text { waste generation }\end{array}$ & $\begin{array}{c}\text { PC } \\
\text { WG }\end{array}$ & $\begin{array}{c}\text { UDPC } \\
\text { WG, } \\
\mathbf{\%}\end{array}$ \\
\hline Kemerovo region & 2801,2 & 51,5 & 67 & The Altay Republic & 0,25 & 54 \\
\hline Krasnoyarsk region & 367,0 & 6,7 & 85,7 & Ivanovo region & 0,24 & 31,3 \\
\hline $\begin{array}{c}\text { The Republic of } \\
\text { Khakassia }\end{array}$ & 259,2 & 4,8 & 75,9 & $\begin{array}{c}\text { The Republic of } \\
\text { North Ossetia- } \\
\text { Alania }\end{array}$ & 0,13 & 62,3 \\
\hline $\begin{array}{c}\text { The Republic of } \\
\text { Sakha (Yakutia) }\end{array}$ & 248,1 & 4,6 & 47,3 & $\begin{array}{c}\text { The Chechen } \\
\text { Republic }\end{array}$ & 0,12 & 0 \\
\hline Murmansk region & 199,6 & 3,7 & 28,1 & $\begin{array}{c}\text { Jewish Autonomous } \\
\text { Region }\end{array}$ & 0,12 & 47,8 \\
\hline
\end{tabular}


Continuation of Table 2.

\begin{tabular}{|c|c|c|c|c|c|c|} 
Transbaikal region & 186,6 & 3,4 & 71,4 & Sevastopol & 0,1 & 8,5 \\
\hline Sverdlovsk region & 168,7 & 3,1 & 43,8 & $\begin{array}{c}\text { The Kabardino- } \\
\text { Balkarian Republic }\end{array}$ & 0,05 & 12,4 \\
\hline Belgorod region & 144,9 & 2,7 & 27,2 & $\begin{array}{c}\text { The Republic of } \\
\text { Dagestan }\end{array}$ & 0,05 & 17,1 \\
\hline $\begin{array}{c}\text { The Republic of } \\
\text { Karelia }\end{array}$ & 134,0 & 2,5 & 13,1 & $\begin{array}{c}\text { The Republic of } \\
\text { Kalmykia }\end{array}$ & 0,01 & 1,4 \\
\hline Irkutsk region & 130,4 & 2,4 & 87,1 & $\begin{array}{c}\text { The Republic of } \\
\text { Ingushetia }\end{array}$ & 0,01 & 7,8 \\
\hline
\end{tabular}

Designation of indicators:

PC WG - Production and consumption waste generation, million tons

SPC WG - Share of production and consumption waste generation, $\%$ of all-Russian

UDPC WG - Usage and neutralization of production and consumption waste in \% of total production and consumption waste generated

Analysis of Table 2 data showed that the reasons for differentiation of regions by the level of waste generation and their processing are the level of industrial production development, population size and size of the region's territory [2; 3].

Thus, empirical analysis has shown that in Russia there is a high level of waste generation, and the highest contribution to the formation of waste is made by the extractive industries. However, consideration of the problem of waste generation and utilization at the regional level has revealed a high differentiation of regions by the indicators under consideration, which is due to the uneven location of natural resources and factors contributing to industrial production development.

\section{Conclusion}

The results of the theoretical analysis show that formation of a unified environmental policy, including in the sphere of waste education and utilization, should be aimed at forming framework rules for sustainable development goals of the country and the region. And the Russian Federation has adopted such documents and established an institutional framework for achieving environmental goals of sustainable development [13].

However, data obtained on the basis of empirical analysis show a high level of differentiation between regions in terms of waste generation and utilization, which confirms the need to enhance the role of regional industrial and environmental policies and strengthen the environmental institutional structure of regions in the form of regional waste management programs.

Regional policy, firstly, should be based on an environmentally-oriented industrial policy, which is associated with the modernization of traditional industries based on the fifth and sixth technological patterns [14, p.9].

Secondly, an institutional structure for environmental industrial policy should be developed in the regions, which should include:

- program and project mechanisms of waste management based on scientifically grounded ecological indicators for the region [13, p.815; 15, p.461];

- development of waste management infrastructure: recycling plants [13, p.815], transport and logistics systems, coordinating organizations and social entrepreneurship [16];

- development of environmentally-oriented behavior not only in production, but also in consumption. 
In general, analysis of the problem of waste generation and utilization to achieve sustainable development goals requires not only interdisciplinary research, but also coordination of efforts of all economic entities in the process of economic activity.

\section{References}

1. G.Mattheus, Procedia Engineering, 33 (2012)

2. S.G. Barnabas, G.D. Sivakumar, G. Satish Pandian, K. Arun Vasantha Geethan, S.P. Kumar, P.P. Rajeevan, P.D. Kumar, Eco. Env. \& Cons., 23 (2017)

3. J.Lepawsky, Waste and Waste Management. International Encyclopedia of Geography: People, the Earth, Environment and Technology, 2017

4. Manual on waste statistics - A handbook for data collection on waste generation and treatment. European Union, Eurostat, 2013

5. O.V.Komarova, L.A.Kezhun, IOP Conference Series: EES, 032219, (2019)

6. O.I.Likhacheva, P.M. Sovetov, Economic and Social Changes- Facts, Trends, Forecast, 10(4) (2017)

7. V.V.Moseiko, Russian J.of Economic Theory, 17(2) (2020).

8. D.C. Wilson, C. Velis, C. Cheeseman, Habitat Int., 30 (2006)

9. F. Biermann, N. Kanie, R.E Kim, CRUST, 26-27 (2017)

10. A. Demirbas, Energ Convs Manage, 52 (2011)

11. S. Needhidasan, M. Samuel, R. Chidambaram, J. Environ Health Sci Eng, 12 (2014)

12. I.G. Polyanskaya, V.V. Yurak, Economy of Region, 14(3) (2018)

13. I.M. Potravny, N.N. Yashalova, V.V. Gassiy, K.Y. Chavez Ferreyra, Economy of region, 15(3) (2019)

14. Ya.P.Silin, Ye.G.Animitsa, N.V. Novikova, The Manager, 2(66) (2017)

15. E.S.Tshovrebov. Proceedings of Moscow State University of Civil Engineering, 14(4) (2019)

16. H.Seddighi, S.Mathew, JIK, (2020) 